\title{
Assessment of forest degradation condition in Natmataung National Park Watershed, Myanmar
}

\author{
YADANAR OO ${ }^{1,2}$, WATHINEE SUANPAGA ${ }^{2, \boldsymbol{v}}$, PONTHEP MEUNPONG $^{2}$ \\ ${ }^{1}$ Department of Forestry, Ministry of Natural Resources and Environmental Conservation. Naypyitaw 15011, Myanmar. \\ ${ }^{2}$ Department of Silviculture, Faculty of Forestry, Kasetsart University. 50 Phahonyothin Rd, Lat Yao, Chatuchak, Bangkok 10900, Thailand \\ Tel./fax.: +66-81-9719789, ^email: wathinee.s@ku.ac.th
}

Manuscript received: 11 November 2020. Revision accepted: 18 February 2021.

\begin{abstract}
Oo Y, Suanpaga W, Muenpong P. 2021. Assessment of forest degradation condition in Natmataung National Park Watershed, Myanmar. Biodiversitas 22: 1354-1362. Natmataung National Park (NTNP) is an important biodiversity hotspot in Myanmar, yet it is threatened by various anthropogenic activities, leading to deforestation and forest degradation. As such, the park needs to be restored to bring back its main function of conserving biodiversity. Ecological restoration in NTNP needs assessment of forest restoration potential through forest degradation condition. This research aimed: (1) to assess forest stand parameters of tree density, basal area, Above Ground Biomass (AGB), and Above Ground Carbon (AGC) at plot level and study area level through sampling with fixed area in the NTNP watershed, (2) to compare the accessed forest stand parameters of old-growth forest (OF) and secondary forest (SF) (per plot individual level and per stem individual level) and tree species richness and diversity of OF and SF (per plot individual level only) in order to know the forest degradation condition. A total of 69 square plots were sampled to achieve such aims. This study found two main results: (1) the estimation of stand parameters in both OF and SF at the plot level and study area level had acceptable statistical proration: (2) stand parameters at stem level had significant differences in which OF had overall higher values of parameters than in SF. Based on the results of this study, we recommend that the OF sites should be conserved through sustainable forest management, while the SF sites should be restored to mimic condition in OF through the implementation of assisted natural regeneration (ANR) with highest dominant native tree species, and the abandoned fallow lands should be restored using pioneer native tree species.
\end{abstract}

Keywords: Deforestation, forest degradation, forest restoration, old-growth forest, secondary forest

\section{INTRODUCTION}

Myanmar has established and managed protected areas for biodiversity conservation accord to the legislative and regulatory framework of the Protection of the Wildlife and Protected Area Law. Yet, the country is still facing deforestation, forest degradation, and loss of habitats within and around the protected areas. Natmatuang National Park (NTNP) is the only Indo-Myanmar biodiversity hotspot located in the eastern Himalayan mountain range. Nonetheless, it is also undergoing the challenges of deforestation, forest degradation, and loss of habitats due to major threats, namely collection of nontimber forest products, illegal hunting, settlement encroachment, road expansion, and upgrading, as well as shifting cultivation (Aung 2012; Aung et al. 2015; Forest Department 2018). In particular, unsustainable shifting cultivation system with short-fallow period by local communities living under extreme poverty combined with the high forest dependence makes the problem worse. As such, it is complicated for the park management especially in managing the abandoned fallow lands and also the delayed nomination process due to the existing conflicts between the park and local people (Meyers 2014; Aung 2020).

On abandoned fallow lands, there is an emerging concern for forest restoration. Yet, fundamental knowledge of ecological succession processes on these lands, either through passive or active restoration, is limited, burgeoning science and practice of ecological restoration (Jacobs et al. 2015; Walker and Del Moral 2009). One important aspect to reveal is the assessment of forest conditions to seek forest restoration potentials by analyzing ecological succession, recruitment, competition, mortality, and species turnover (Budiharta et al. 2014). Over the last two decades, investigation of the pattern of species diversity and biomass recovery in secondary forests on former swidden land plays a major role in growing research interest in Southeast Asia (Suryanto et al. 2017). The updated results, including species diversity and forest stand structure data, can provide appropriate guidelines for developing effective forest conservation and management (Aye et al. 2014).

Because the abandonment of fallow lands widespread throughout the NTNP, assessment of forest condition to identify restoration potential in the park is urgently required with the final goal to recover and conserve tropical biodiversity. Therefore, this research aimed: (i) to assess forest degradation condition in the NTNP with parameters of tree density, basal area, Above Ground Biomass (AGB), and Above Ground Carbon (AGC) at plot level and study area level through sampling with fixed area, (ii) to compare forest condition in old-growth forest (OF) and secondary forest (SF) per plot individual level and per stem individual level and tree species richness and diversity of OF and SF per plot individual level. To achieve these objectives, we posed two research questions; (i) What are 
the quantities of estimated forest stand parameters at plot level and study area level in NTNP watershed with reliable statistical prorations of Standard Deviation (SD), Standard Error Percent (SE\%), Margin of Error Percent (MOER\%), and Coefficient of Variation $(\mathrm{CV} \%)$ at $95 \%$ confidence interval?; (ii) Does the estimated forest stand parameters and tree species diversity of OF and SF differ per plot individual level or per stem individual level?

\section{MATERIALS AND METHODS}

\section{Study period and area}

The study was conducted in the watershed area of NTNP at Kanpetlet Township, Chin State, western part of Myanmar. The study period is started from 9 October 2019 to 29 December 2019 . The 1,814 ha of NTNP watershed location is geographically located in $21^{\circ} 15^{\prime} 10.73^{\prime \prime} \mathrm{N}$ to $22^{\circ} 13^{\prime} 24.25^{\prime \prime} \mathrm{N}$ and $93^{\circ} 57^{\prime} 25.10^{\prime \prime} \mathrm{E}$ to $93^{\circ} 57^{\prime} 22.21^{\prime \prime} \mathrm{E}$. The slope ranges from $0.34^{\circ}$ to $50.73^{\circ}$ and the elevation ranges from $1,520 \mathrm{~m}$ to $2,979 \mathrm{~m}$ above sea level (asl). In general, the forest type is semi-evergreen montane forest with specific forest type of Laurel forest (Fujikawa et al. 2008).

The study sites of old-growth forest (OF) and secondary forest (SF) are located between the $8^{\text {th }}$ mile and $10^{\text {th }}$ mile of NTNP. Some studied areas of OF were cleared to grow black pumpkin last few years ago. Moreover, the illegal logging was experienced in another place of OF near $10^{\text {th }}$ mile of NTNP, which is near Mount Victoria. In this study, the SF and OF categorization is fundamentally based on elevation criteria (Forest Department 2018, Fujikawa et al. 2008), human disturbance, indigenous knowledge and field experience. Although by definition, the altitude of SF is below 2,286 $\mathrm{m}$ asl or 7,500 $\mathrm{ft}$, in the present study, the threshold for SF was defined between 1,990-2,380 $\mathrm{m}$ asl with medium disturbance. The OF of this research was set between 2,380 $\mathrm{m}$ and 3,000 $\mathrm{m}$ asl with low disturbance. According to the Department of Metrology and Hydrology, Mindat Township, the total annual rainfall from 2005 to 2019 was $1,621.61 \mathrm{~mm}$, the mean annual temperature was $21.72{ }^{\circ} \mathrm{C}$ and the mean aridity index is 47.78 . The map of the study sites of OF and SF in NTNP watershed, Kanpetlet Township, Chin State, Myanmar is presented in Figure 1.

\section{Data collection for forest inventory}

The secondary data of Digital Elevation Model with 30 $\mathrm{m}$ resolution was downloaded from https://earthexplorer.usgs.gov in order to create the NTNP watershed boundary with the assistance of the Soil and Water Assessment Tool (SWAT) in ArcGIS 10.5. Statistically, the 74 planned sample plots (n) of this study were anticipated to achieve the desired MOER\% $\left(\mathrm{d}_{\mathrm{r}}\right)$ with previous inventory result of $\mathrm{CV} \%$ and $\mathrm{t}$ value at $95 \%$ confidence interval based on the sample size equation $\mathrm{n}=$ $\left(\mathrm{t}^{2} \times \mathrm{r}_{\mathrm{y}}^{2}\right) / \mathrm{d}_{\mathrm{r}}^{2}$ (Gregoire and Valentine 2007). Based on the equation of $\mathrm{d}_{\mathrm{r}}=\left(\mathrm{t} \times \mathrm{r}_{\mathrm{y}}\right) / \sqrt{\mathrm{n}}$, the preliminary MOER $\%$ and actual MOER\% were calculated (Gregoire and Valentine 2007, Myint et al. 2017). To get the preliminary desired
MOER\% $\left(\mathrm{d}_{\mathrm{r}}=13.86 \%\right)$ of this study, the preliminary anticipated sample plots $(n=74)$, the previous inventory result of CV\% at Siyin/Segyi Reserved Forest Pilot Study Area in Chin State by Myint et al. (2017) $\left(\mathrm{r}_{\mathrm{y}}=60 \%\right)$, and $\mathrm{t}$ value at $95 \%$ confidence interval $(\mathrm{t}=1.994945)$ were statistically estimated. In this study, the actual MOER\% values of forest stand parameters were prorated based on the actual CV\% of respective parameters based on total 69 accessible plots.

Although the 74 systematic sample plots with the 0.04 ha sample size $\left(20 \mathrm{~m} \times 20 \mathrm{~m}=400 \mathrm{~m}^{2}\right)$ per plot and $500 \mathrm{~m}$ sampling distance were primarily created in ArcGIS 10.5, we sampled only total 69 accessible plots because the remaining 5 plots were inaccessible as they were located at very steep slopes or cliffs or very thorny scrublands. Among the 69 total accessible sample plots with $500 \mathrm{~m}$ systematic sampling distance within 0.04 ha, only 27 plots of abandoned fallow lands were not covered with tree species because of the abundance of thick herbs, shrubs, and climber species. The total accessible 69 square sample plots were conducted for the collection of all measurable trees of $\geq 5 \mathrm{~cm}$ of diameter at breast height $(\mathrm{DBH})$ and $\geq$ $1.3 \mathrm{~m}$ in height $(\mathrm{H})$.

\section{Data analysis}

The estimated tree stand parameters including tree density, basal area, AGB, and AGC for whole study area of NTNP watershed were calculated based on these total 69 accessible plots (42 plots with trees and 27 plots with no tree). The comparisons between tree species diversity and estimated forest resources of both investigated stands were calculated based on the only 42 plots with trees (24 OF's plots and 18 SF's plots). The mean and total values of estimated AGB and AGC of this study were derived by using the specific allometric AGB equation of dry evergreen forest (Senpaseuth et al. 2009). The mean sitespecific AGB of plot-level was calculated as the simple arithmetic average of generalized plot results. The total and mean AGC at plot level was estimated by multiplying 0.47 (Goslee et al. 2016).

From the field inventory data based on these total 69 accessible plots, the NTNP watershed area's forest resources estimation at $95 \%$ confidence interval was accomplished by sampling strategies for natural resources and environment with the sampling with fixed area plots (Gregoire and Valentine 2007). The independent estimator $\left(\hat{\mathrm{T}}_{\mathrm{yms}}\right)$ of total population for each forest resource parameter with the important statistical prorations (SD, $\mathrm{SE} \%, \mathrm{MOER} \%$, and $\mathrm{CV} \%$ ) at plot level and study area level were computed (Myint et al. 2017). The each of total population $\left(\mathrm{T}_{\mathrm{y}}\right)$ of estimated forest resource parameter per plot level was transformed into study area level by multiplying 1,814 ha and dividing 0.04 ha. The $\hat{\mathrm{T}}_{\mathrm{yms}}$ of estimated forest resources values for both the plot level and study area level were derived as the sum of respective estimated forest resource values of $\mathrm{T}_{\mathrm{y}}$. The overall sampling intensity percent $(\% \mathrm{SI})$ for all of the forest resource estimations was $0.15 \%$. 


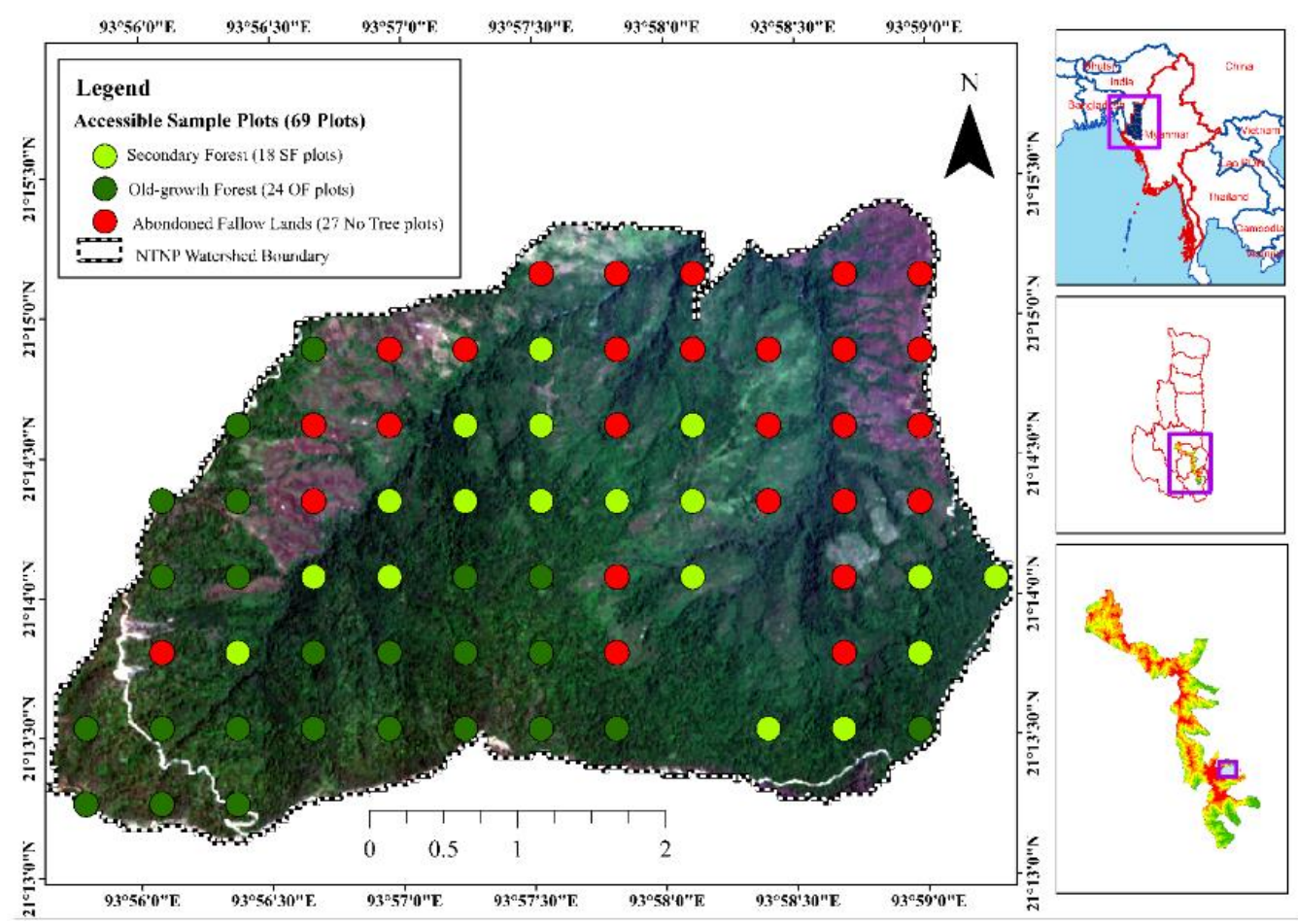

Figure 1. Map of study sites of old-growth forest (OF) and secondary forest (SF) in Natmataung National Park Watershed, Kanpetlet Township, Chin State, Myanmar

From the surveyed vegetation data based on the 42 accessible tree plots, forest tree species composition, horizontal forest stand structure, and species diversity indices of OF and SF and their differences were analyzed (Narayan and Anshumali 2015). For assessing the ecological importance or significance of tree species, species-level important value index (IVI) was calculated as the summing up of Relative Abundance (RA), Relative Dominance (RDo), Relative Frequency (RF) of species level (Chowdhury et al. 2018) based on the 24 plots of OF and 18 plots of SF. To provide quantitative estimates of species diversity of $\mathrm{OF}$ and $\mathrm{SF}$, the species richness values or the number of species in each community (Colwell 2009), Simpson's index (1-D'), and Shannon-Wiener index $\left(\mathrm{H}^{\prime}\right)$, and Evenness Index $\left(\mathrm{J}^{\prime}\right)$ were used (Ifo et al. 2016). The coefficient of species similarity indices such as Sorensen's quantitative index $\left(\mathrm{K}_{\mathrm{s}}\right)($ Dent and Wright 2009) and Lamprecht's modification index $\left(\mathrm{K}_{\mathrm{d}}\right)$ (Günter et al. 2007) were also computed in order to compare the similarity of floristic composition of OF and SF. The species-area curve comparison for both stands per sampled area $(\mathrm{OF}$ per sampled area $=0.04$ ha $\times 24$ plots $=0.96$ ha level and SF per sampled area $=0.04$ ha $\times 18$ plots $=0.72$ ha level) was drawn to determine the minimum representative area for each population.

Concerning both stands' forest stand structure results in this research, the arithmetic mean DBH in $\mathrm{cm}$ calculations of $\mathrm{OF}$ and SF were conducted. For a good way for analyzing the forest communities of OF and SF, their size class distribution presenting horizontal stand structure (Zin 2017) in terms of tree density and species richness were conducted. These forest stand structure measurements can not only express the current forest situation but also can apply to other forest silviculture and management practices (Haidari et al. 2013). For the assessment of the horizontal stand structural distributions within $0.04 \mathrm{ha}(20 \mathrm{~m} \times 20 \mathrm{~m}=$ $400 \mathrm{~m}^{2}$ ), all trees of $\geq 5 \mathrm{~cm}$ DBH were categorized into five classes with $30 \mathrm{~cm}$ interval; (1) $\leq 30 \mathrm{~cm}$, (2) $35-65 \mathrm{~cm}$, (3) $65-95 \mathrm{~cm}$, (4) $95-125 \mathrm{~cm}$, and (5) $\geq 125 \mathrm{~cm}$. We used the Two Independent Samples Unequal Variance T-Test to determine the differences in mean species richness, diversity indices including $\mathrm{H}^{\prime}, 1-\mathrm{D}^{\prime}$, and $\mathrm{J}^{\prime}$ of $\mathrm{OF}$ and $\mathrm{SF}$ of both OF and SF. We also detected the Two Independent Samples Unequal Variance T-Test to examine the differences in total tree density, basal area, total of AGB and AGC of both stands. The statistical results between two investigated stands per plot individual level and per stem individual level of this research were achieved.

\section{RESULTS AND DISCUSSION}

\section{Forest stand parameters}

The estimated means of tree density, basal area, AGB, and AGC per 0.04 ha were $10.58 \pm 0.16$ trees, $0.81 \pm 0.01 \mathrm{~m}^{2}$, $8.92 \pm 0.12$ tons, $4.19 \pm 0.07$ tons, respectively. Although the preliminary MOER\% of overall forest estimation was prorated with $13.86 \%$, the actual MOER\% results of present study failed to achieve this value due to the high $\mathrm{CV} \%$ representing the heterogeneous forest type (ranging from $110 \%$ to $130 \%$ ). However, the present results of SE\% (ranging from 13\% to 16\%) and MOER\% (ranging from 
$26 \%$ to $31 \%$ ) were nearly similar to previous pilot study of SE\% (ranging from $10 \%$ to $13 \%$ ) and MOER\% (ranging from $16 \%$ to $21 \%$ ) at Siyin/Segyi Reserved Forest in Chin State. In addition, the acceptable MOER\% can be assumed as $20 \%$ to $28 \%$ and the acceptable SE\% could be also remarked as $12 \%$ to $16 \%$ (Myint et al. 2017). Therefore, these achieved statistical results of SE\% and MOER\% of NTNP watershed could assume as reliable results (Table 1).

Based on the highest result (130 CV\%) of study area, the achievement of the future desired 10\% MOER\% proration for similar land-use patterns of another area in NTNP, which are mainly composed with OF and SF will require at least 650 sample plots, while the achieving $15 \%$ MOER\% proration of similar land-use patterns will need at least 300 sample plots. The results of this study suggested that the estimated forest stand parameters with acceptable SE\% and MOER\% of this research (total tree density, basal area, AGB, and AGC) could beneficially apply the evidence for current forest situation of study area as the baseline data for further researches, forest cover improvement, and forest carbon enhancement.

\section{Forest composition and structure}

\section{Species-area relationship}

According to the species-area curve patterns of $\mathrm{OF}$ and SF in NTNP (Figure 2), both of the curve patterns were slightly similar. The OF species curve occupied 6 tree species and SF species curve had 9 tree species in the first plot at $400 \mathrm{~m}^{2}$. The OF curve ended at $9,600 \mathrm{~m}^{2}$ having 35 tree species, while the SF species curve ended at 7,200 $\mathrm{m}^{2}$ having 32 tree species. Although the OF curve climbed gradually with 32 tree species, the SF curve went up slightly fluctuated with 28 tree species at $5,600 \mathrm{~m}^{2}$. At $7,200 \mathrm{~m}^{2}$, both of the forests were leveled off with the same number of 32 forest tree species. The species number in $\mathrm{OF}$ increased by $6.06 \%$ (33 species in 7,600 $\mathrm{m}^{2}$ and 35 species in $9,600 \mathrm{~m}^{2}$ ) while that in SF increased by $3.23 \%$ (31 species in $6,000 \mathrm{~m}^{2}$ and 32 species in $7,200 \mathrm{~m}^{2}$ ). According to Khaing and Mitloehner 2014, the minimum sampling area is acceptable when the occurrence of newly founded species remains below $10 \%$ with a $10 \%$ expansion in the sample area. Therefore, these respective small increased percentage results with below $10 \%$ of both stands of this study represented the minimum sampling area for $\mathrm{OF}$ and SF.

\section{Tree species diversity and composition}

Among a total of 42 tree species (730 tree individuals, 24 families, $55.66 \mathrm{~m}^{2}$ basal area) of the present study in the NTNP watershed area, 35 tree species (394 tree individuals, 21 families, $36.47 \mathrm{~m}^{2}$ basal area) were found at OF and 32 species (336 tree individuals, 20 families, 19.16 $\mathrm{m}^{2}$ basal area) were found at SF, respectively.

The most dominant tree species in the two investigated stands were Lithocarpus xylocarpus, Neolitsea zeylanica, Schima wallichii, and Myrsine semiserrata, with $L$. xylocarpus had the highest species important value index (IVI) for both stands, while the rarest species of both stands were Cephalotaxus mannii, Docynia indica, Mahonia nepalensis, Schima khasiana, Ficus semicordata, Lingustrum sp., and Machilus robusta (Table 2). The most dominants tree species of two investigated stands showed that the characteristics of regular horizontal distributions because they also have high proportion of abundance, dominance and frequency of the total IVI. Although the average $\mathrm{DBH}$ and $\mathrm{H}$ of both investigated stands showed the reverse J-shaped curves, conservation activities combined with planting of pioneer native tree species and highest IVI species at degraded forest area and currently abandoned land are needed.

Amongst the most common species described in other studies (Myat 2016), the two most dominant species of $L$. xylocarpus and $S$. wallichii are similar in comparison with this study. Other studies in subtropical evergreen forests with 77 species richness in Japan (Feroz et al. 2009) and tropical forests with 73 species in Central Africa (RéjouMéchain et al. 2008) showed that these two types are 1.8333 times and 1.7381 times larger than the 42 overall species richness (35 OF species richness and $32 \mathrm{SF}$ species richness) of present study in NTNP watershed area.

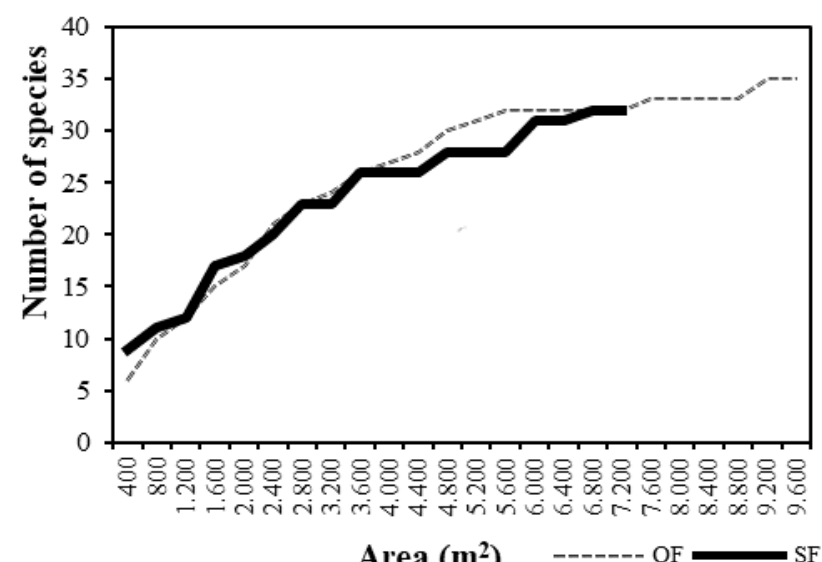

Figure 2. Species area curves between old-growth forest (OF) and secondary forest (SF) in Natmataung National Park Watershed, Myanmar

Table 1. The estimation of forest stand parameters of study area in Natmataung National Park Watershed, Myanmar

\begin{tabular}{lccccc}
\hline Forest stand parameters & $\hat{\mathrm{T}}_{\text {yrs }}$ at plot level & $\hat{\mathrm{T}}_{\text {yrs }}$ at study area level & SE\% & MOER\% & CV\% \\
\hline Tree Density (n) & 730 & $33,105,500.00$ & 12.90 & 25.70 & 107.20 \\
Basal Area (m2) & 55.63 & $2,524,305.56$ & 14.60 & 29.02 & 121.80 \\
AGB (tons) & 615.64 & $27,919,274.00$ & 15.60 & 31.20 & 130.80 \\
AGC (tons) & 289.35 & $13,122,022.50$ & 15.60 & 31.20 & 130.80 \\
\hline
\end{tabular}

Note: ${ }^{\hat{\mathrm{T}}_{\mathrm{yms}}}$ at plot level: Total Forest stand parameters at plot level; ${ }^{. \hat{\mathrm{T}}_{\mathrm{yms}}}$ at study area level: Total Forest stand parameters at study area level 
Table 2. Nine most important tree species in old-growth forest (OF) and secondary forest (SF) based on Important Value Index (IVI) in Natmataung National Park Watershed, Myanmar

\begin{tabular}{|c|c|c|c|c|c|c|}
\hline \multirow{2}{*}{$\begin{array}{l}\text { Forest } \\
\text { type }\end{array}$} & \multirow{2}{*}{ Rank } & \multirow{2}{*}{ Species name } & \multicolumn{3}{|c|}{ Absolute } & \multirow{2}{*}{ IVI (\%) } \\
\hline & & & Abundance (stems) & Dominance $\left(\mathbf{m}^{2}\right)$ & Frequency (\%) & \\
\hline \multirow{10}{*}{ 步 } & 1 & Lithocarpus xylocarpus & 91 & 17.83 & 13.64 & 85.62 \\
\hline & 2 & Neolitsea zeylanica & 45 & 2.52 & 12.12 & 30.44 \\
\hline & 3 & Quercus semecarpifolia & 14 & 3.72 & 6.06 & 19.80 \\
\hline & 4 & Osmanthus fragrans & 24 & 1.61 & 5.30 & 15.81 \\
\hline & 5 & Machilus dumicola & 17 & 2.02 & 5.30 & 15.16 \\
\hline & 6 & Schima wallichii & 17 & 1.37 & 4.55 & 12.62 \\
\hline & 7 & Machilus thunbergii & 10 & 1.59 & 4.55 & 11.45 \\
\hline & 8 & Myrsine semiserrata & 18 & 0.19 & 3.79 & 8.89 \\
\hline & 9 & Prunus cerasoides & 13 & 0.78 & 3.03 & 8.47 \\
\hline & 10 & Others (26) & 145 & 4.84 & 41.67 & 91.74 \\
\hline \multirow[t]{5}{*}{ Total (35) } & & & 394 & 36.47 & 100 & 300 \\
\hline & 1 & Lithocarpus xylocarpus & 79 & 7.52 & 13.86 & 76.64 \\
\hline & 2 & Schima wallichii & 37 & 2.16 & 11.88 & 34.18 \\
\hline & 3 & Myrsine semiserrata & 33 & 1.10 & 4.95 & 20.49 \\
\hline & 4 & Alnus nepalensis & 19 & 1.52 & 4.95 & 18.56 \\
\hline \multirow{6}{*}{ 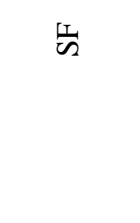 } & 5 & Neolitsea zeylanica & 21 & 0.78 & 7.92 & 18.27 \\
\hline & 6 & Engelhardia spicata & 17 & 0.86 & 7.92 & 17.45 \\
\hline & 7 & Macropanax dispermus & 22 & 0.59 & 6.93 & 16.55 \\
\hline & 8 & Schefflera hypoleucoides & 8 & 0.80 & 4.95 & 11.50 \\
\hline & 9 & Quercus semecarpifolia & 3 & 0.95 & 1.98 & 7.81 \\
\hline & 10 & Others (23) & 97 & 2.88 & 34.65 & 78.55 \\
\hline Total (32) & & & 336 & 19.16 & 100 & 300 \\
\hline
\end{tabular}

Table 3. The tree species richness, diversity indices, coefficients of similarity and their statistical test results per plot individual level in Natmataung National Park Watershed, Myanmar

\begin{tabular}{|c|c|c|c|c|c|c|c|}
\hline \multirow{2}{*}{\multicolumn{2}{|c|}{ Forest type }} & \multirow{2}{*}{ Species richness (n) } & \multicolumn{3}{|c|}{ Diversity indices } & \multicolumn{2}{|c|}{ Coefficient of similarity } \\
\hline & & & 1-D' & $\mathbf{H}^{\prime}$ & $\mathbf{J}^{\prime}$ & $\mathbf{K}_{\mathrm{s}}$ & $K_{d}$ \\
\hline OF & & 35 & 0.9151 & 2.9570 & 0.8317 & $71.64 \%$ & $93.64 \%$ \\
\hline SF & & 32 & 0.9065 & 2.8338 & 0.8177 & & \\
\hline T-Test & T Value & 2.0262 & 2.0211 & 2.0281 & 2.0227 & - & - \\
\hline & $\mathrm{P}$ Value & 0.8828 & 0.8404 & 0.9126 & 0.3050 & & \\
\hline
\end{tabular}

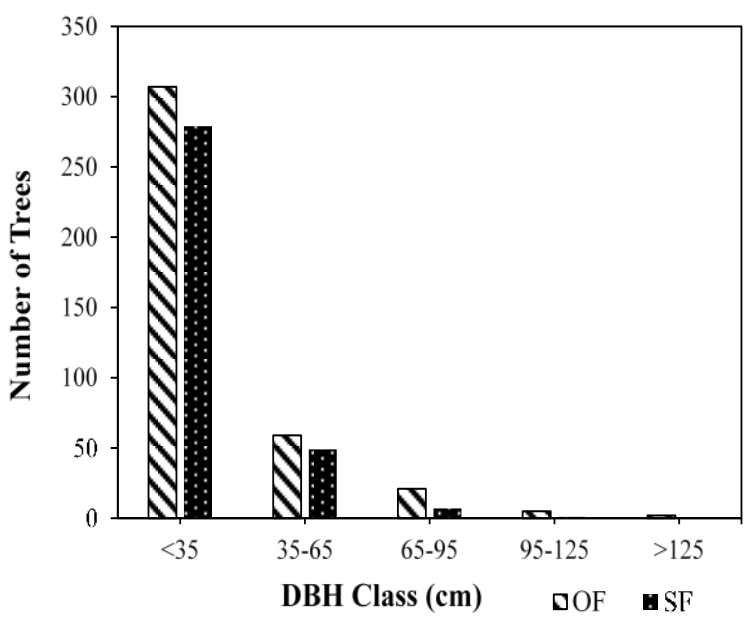

Figure 3. Diameter class distribution based on individual number of trees in old-growth forest (OF) and secondary forest (SF) in Natmataung National Park Watershed, Myanmar

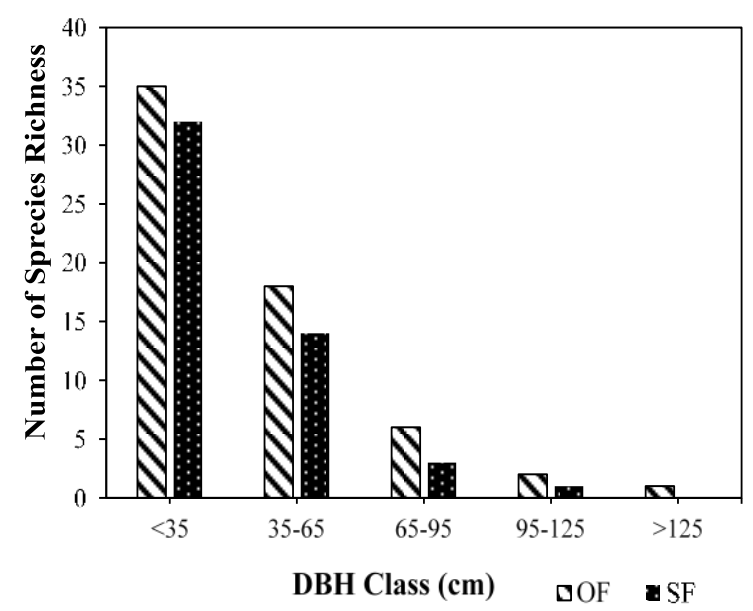

Figure 4. Diameter class distribution based on number of species richness in old-growth forest (OF) and secondary forest (SF) in Natmataung National Park Watershed, Myanmar 
Nine species with the highest ranks occupied more than half of the total IVI value with 249 tree individuals and $31.63 \mathrm{~m}^{2}$ in $\mathrm{OF}$ and 239 tree individuals and $16.28 \mathrm{~m}^{2}$ in $\mathrm{SF})$. This result suggests that the $\mathrm{OF}$ was dominated by larger diameter trees while the SF was dominated by smaller diameter trees, implying forest restoration potential in the SF. The restoration can be conducted through Assisted Natural Regeneration (ANR) and/or framework species method with pioneer native tree species because these ecological restoration methods have a good performance as the effective ecological restoration success (Lu et al. 2017). The pioneer native trees species in present study were Alnus nepalensis (Rana et al. 2008), Quercus semecarpifolia (Sharma et al. 2009), L. xylocarpus (Li et al. 2010), Rhododendron arboretum (Sharma et al. 2009), S. wallichii (Enoki et al. 2014), Eurya sp. (Enoki et al. 2014), Symplocos racemosa (Sofia and Karishma 2013), and Symplocos ramosissima (Sofia and Karishma 2013). Amongst these pioneer native tree species, A. nepalensis (early-successional forest species) and S. wallichii (midsuccessional forest species) were wind-dispersed (Lu et al. 2016, Lu et al. 2017). In addition, the A. nepalensis is ecologically important pioneer species due to fast-growing and nitrogen-fixing species (Rana et al. 2008). According to the rates of seed germination, seedling survival, and growth described by Lu et al. 2017, species with high potential were $A$. nepalensis, while those with marginal potential were $S$. wallichii and $M$. semiserrata. In summary, these 8 pioneer native tree species and highest IVI native species are recommended for restoration activities in the NTNP.

The species diversity indices in OF and SF were 0.9151 and 0.9064 (1-D'), 2.9570 and $2.8338\left(\mathrm{H}^{\prime}\right)$, as well as 0.8317 and $0.8176\left(\mathrm{~J}^{\prime}\right)$, respectively (Table 3$)$. Although OF had slightly higher species diversity than SF, both stands were nearly similar. In this study, tree species of both stands were almost equally abundant as their $\mathbf{J}^{\prime}$ percentages were nearly close to 1 (Myat 2016, Zin 2017). For the results of the coefficient of floristic similarity indices based on the 24 common species, $\mathrm{K}_{\mathrm{s}}$ and $\mathrm{K}_{\mathrm{d}}$ values were $71.64 \%$ and $93.64 \%$, respectively. Moreover, the no significant differences between the diversity indices in $\mathrm{OF}$ and SF at plot individual level showed the near similar status of OF and SF. Previous study in NTNP (Myat 2016) showed that species diversity indices of OF and SF were 0.96 and 0.95 of 1-D', 3.34 and 3.51 of $\mathrm{H}^{\prime}$, as well as 0.81 and 0.86 of $\mathbf{J}^{\prime}$, indicating that species diversity is almost similar with the present study.

Statistically, the test results of $1-\mathrm{D}^{\prime}, \mathrm{H}^{\prime}$, and $\mathrm{J}^{\prime}$ indices and species richness did not demonstrate significant differences between the two forest types at plot individual level when the T-test of Two Independent Samples Equal Variance Test with two tails was used (all $\mathrm{p}$ values $>0.05$ ). In summary, the diversity indices of two investigated stands proved that these were indeed heterogeneous forest types although OF had more heterogeneity than SF.

\section{Stand structure}

Trees with $<35 \mathrm{~cm}$ DBH class had highest densities among other classes with 307 individuals in OF and 297 individuals in SF, followed by trees with 35-65 cm DBH class which were also nearly similar in both of these investigated stands (Figure 3). In contrast, trees with DBH between $>65 \mathrm{~cm}$ and $<155 \mathrm{~cm}$ were significantly low in number. At DBH class of $65-95 \mathrm{~cm}, 21$ individuals were recorded in the OF and only 8 individuals were found in the SF. For DBH classes of $95-125 \mathrm{~cm}$ and $125-155 \mathrm{~cm}$, there was no individual in the SF which was likely due to the disturbance of shifting cultivation.

In terms of diameter class distribution based on species, all species in both stands ( 35 species in OF and 32 species in SF) were represented in diameter class of $<35 \mathrm{~cm} \mathrm{DBH}$ (Figure 4). In addition, $51.43 \%$ of all species in OF and $43.75 \%$ of SF had DBH class of $35-65 \mathrm{~cm}$. For the rest of tree largest DBH classes of both investigated forests, only small proportions of all species were found only in OF.

Based on the total plot area of this research, both stands' overall total values of forest resource parameters were $55.63 \mathrm{~m}^{2}$ of total basal area $\left(36.47 \mathrm{~m}^{2}\right.$ of $\mathrm{OF}$ and $19.16 \mathrm{~m}^{2}$ of SF), 28.45 tons of mean AGB (17.27 tons of $\mathrm{OF}$ and 11.18 tons of SF), 13.37 tons of mean AGC (8.12 tons of OF and 5.25 tons of SF), 615.64 tons of total AGB (414.41 ton of OF and 201.23 tons of SF), 289.35 tons of total AGC (194.77 ton of OF and 94.58 tons of SF), $17,111.70 \mathrm{~cm}$ of total DBH $(9,920.23 \mathrm{~cm}$ of $\mathrm{OF}$ and $7,191.47 \mathrm{~cm}$ of SF), 7,681.10 $\mathrm{m}$ of $\mathrm{H}(4,003.35 \mathrm{~m}$ of $\mathrm{OF}$ and $3,677.74 \mathrm{~m}$ of SF), and 730 stems of tree stems (394 stems of $\mathrm{OF}$ and 336 stems of SF), respectively.

The OF's present total basal area was smaller than 0.7039 times than $51.81 \mathrm{~m}^{2}$ of past total basal area (Myat 2016) while SF's present total basal area was smaller than 0.9141 of $20.96 \mathrm{~m}^{2}$ of previous total basal area (Myat 2016). These results showed that the present total basal areas of both stands were similar to total basal area of past research. The AGB values in $\mathrm{OF}$ in this study are greater than that reported by Yirdaw et al. 2019 at Napo (lower mixed deciduous forest) and Dong $\mathrm{Na}$ Tard (upper mixed deciduous forest and an upper dry evergreen forest) which are situated in the Vientiane prefecture and Savannakhet Province, Laos. However, AGB amount in SF in this study is significantly greater than those sites in Laos. In more detail, AGB values in OF in our study represents 1.4284 times of the Napo's OF and 1.7045 times of Dong Na Tard's OF, while AGB in SF is equal to the 19.4425 times of the Napo's SF and 3.7861 times of Dong Na Tard's SF, respectively.

Based on statistical results using T-test, forest stand parameters at individual level had significant differences although per plot, it was not significant (Table 4). Although the two investigated forests appeared to be in good condition, indicated by the stable species with reverse Jshaped curves, OF and SF should preserve nature and biodiversity conservation and should develop conservation plans. The lack of larger stem sizes in the SF can be assumed that impacts of burning and clear-cutting of shifting cultivation in the NTNP watershed area. According to Zin (2017), OF had larger stems than those in SF, despite similar site conditions. This information is corroborated in this study in which large stems were only found abundantly in OF than in SF. 
Table 4. Comparison of forest stand parameters at plot level and stem level in old-growth forest (OF) and secondary forest (SF) in Natmataung National Park Watershed, Myanmar

\begin{tabular}{|c|c|c|c|c|c|c|c|c|}
\hline \multirow[b]{3}{*}{ Forest stand parameters } & \multirow{2}{*}{\multicolumn{2}{|c|}{$\frac{\text { OF }}{\text { Mean } \pm \text { SD }}$}} & \multirow{2}{*}{\multicolumn{2}{|c|}{$\frac{\text { SF }}{\text { Mean } \pm \text { SD }}$}} & \multicolumn{4}{|c|}{ The two independent samples unequal variance T-test } \\
\hline & & & & & \multicolumn{2}{|c|}{ Per plot level } & \multicolumn{2}{|c|}{ Per stem level } \\
\hline & Per plot level & Per stem level & Per plot level & Per stem level & $\mathbf{T}$ & & & $\begin{array}{l}\text {-value } \\
\text { P-value } \\
\text { T-value } \\
\text { P-value } \\
\end{array}$ \\
\hline Tree density (stems) & $16.42 \pm 9.41$ & - & $18.67 \pm 9.96$ & - & 2.0281 & 0.4631 & - & - \\
\hline $\mathrm{DBH}(\mathrm{cm})$ & - & $25.18 \pm 23.38$ & - & $21.4 \pm 16.4$ & 2.0227 & 0.1042 & 1.9639 & 0.0021 \\
\hline Basal Area $\left(\mathrm{m}^{2}\right)$ & $1.52 \pm 1.07$ & $0.09 \pm 0.2$ & $1.06 \pm 0.71$ & $0.06 \pm 0.1$ & 2.0244 & 0.0782 & 1.9642 & 0.0051 \\
\hline AGB (tons) & $17.27 \pm 13.54$ & $1.05 \pm 2.89$ & $11.18 \pm 8.13$ & $0.6 \pm 1.26$ & 2.0244 & 0.0782 & 1.9642 & 0.0051 \\
\hline AGC (tons) & $8.12 \pm 6.37$ & $0.49 \pm 1.36$ & $5.25 \pm 3.82$ & $0.28 \pm 0.59$ & 0.2062 & 0.4189 & 1.9633 & 0.0109 \\
\hline
\end{tabular}


In conclusion, the results of forest composition and forest stand structure in the studied area suggest that NTNP watershed needs ecological restoration by planting pioneer native tree species. The significant differences between forest stand structure parameters in OF and SF highlighted the current forest condition, implying that the SF with remnant trees should be upgraded to nearly OF by ANR. In addition, the open areas with no trees as occurred in the 27 plots critically required forest restoration.

\section{ACKNOWLEDGEMENTS}

This study is financially supported by Kasetsart University (Thailand) Scholarships for ASEAN for Commemoration of the $60^{\text {th }}$ Birthday Anniversary of Professor Dr. Her Royal Highness Princess Chulabhorn Mahidol. We would like to thank all of the staff of Natmataung National Park, Myanmar that helped with our data collection and giving information.

\section{REFERENCES}

Aung PS, Adam YO, Pretzsch J, Peters R. 2015. Distribution of fores income among rural households: A case study from Natma Taung National Park, Myanmar. For Trees Livelihoods 24 (3): 190-201.

Aung PS. 2012. Understanding Forest Dependency and Resource Extraction of Local Communities Living Around the Protected Area in Myanmar: A Case Study in Natma Taung National Park, Myanmar [Dissertation]. Geo and Hydro Sciences of Technische Universitä Dresden, Institute of International Forestry and Forest Products University, Dresden. [Germany]

Aung PS. 2020. Social-Ecological Coevolution and its Implications for Protected Area Management: Case Study in Natma Taung National Park, Myanmar. [Dissertation]. Geo and Hydro Sciences of Technische Universität Dresden, Institute of International Forestry and Forest Products University, Dresden. [Germany]

Aye YY, Pampasit S, Umponstira C, Thanacharoenchanaphas K, Sasaki N. 2014. Floristic composition, diversity and stand structure of tropical forests in Popa Mountain Park. J Environ Protect 5 (17): 1588.

Budiharta S, Meijaard E, Erskine PD, Rondinini C, Pacifici M, Wilson KA. 2014. Restoring degraded tropical forests for carbon and biodiversity. Environ Res Lett 9 (11): 114020.

Chowdhury B, Hossain MK, Hossain MA, Khan BM. 2018. Native tree species diversity of Rampahar natural forest reserve in Rangamati South forest division, Bangladesh. Ceylon J Sci 47 (2): 129-136.

Colwell RK. 2009. Biodiversity: concepts, patterns, and measurement. Princeton Guide Ecol 663: 257-263.

Dent DH, Wright SJ. 2009. The future of tropical species in secondary forests: A quantitative review. Biol Conserv 142 (12): 2833-43.

Enoki T, Kusumoto B, Igarashi S, Tsuji K. 2014. Stand structure and plant species occurrence in forest edge habitat along different aged roads on Okinawa Island, southwestern Japan. J For Res 19 (1): 97-104.

Feroz SM, Min W, Li Y, Sharma S, Suwa R, Nakamura K, Hagihara A, Denda T, Yokota M. 2009. Floristic composition, woody species diversity and spatial distribution of trees based on architectural stratification in a subtropical evergreen broadleaf forest on Ishigaki Island in the Ryukyu Archipelago. Tropics 18 (3): 103-114.

Forest Department, Ministry of Natural Resources and Environmental Conservation, Myanmar. 2018. Natmataung (Khaw Num Cung) National Park Management Plan Forest Department, Ministry of Natural Resources and Environmental Conservation, Myanmar.

Fujikawa K, Kuroiwa N, Maeda A, Gale S, Ngai SG, Din A. 2008. A Guide to the Forests of Natma Taung: Natma Taung National Park, Myanmar. The Kochi Prefectural Makino Botanical Garden, Kochi.

Goslee K, Walker SM, Grais A, Murray L, Casarim F, Brown S. 2016. Module C-CS: calculations for estimating carbon stocks. Leaf technical guidance series for the development of a forest carbon monitoring system for REDD+. Winrock International, USA

Gregoire TG, Valentine HT. 2007. Sampling Strategies for Natural Resources and The Environment. CRC Press, Boca Raton, FL.

Günter S, Weber M, Erreis R, Aguirre N. 2007. Influence of distance to forest edges on natural regeneration of abandoned pastures: A case study in the tropical mountain rain forest of Southern Ecuador. Eur J For Rese 126 (1): 67-75.

Haidari M, Namiranian M, Gahramani L, Zobeiri M, Shabanian N. 2013. Study of vertical and horizontal forest structure in Northern Zagros Forest (Case study: West of Iran, Oak forest). Eur J Exp Biol 3 (1): 268-278.

Ifo SA, Moutsambote JM, Koubouana F, Yoka J, Ndzai SF, BouetouKadilamio LNO, Mampouya H, Jourdain C, Bocko Y, Mantota AB, Mbemba M. 2016. Tree species diversity, richness, and similarity in intact and degraded forest in the tropical rainforest of the Congo Basin: case of the forest of Likouala in the Republic of Congo. Intl $\mathbf{J}$ For Res. 2016: 7593681. DOI: 10.1155/2016/7593681.

Jacobs DF, Oliet JA, Aronson J, Bolte A, Bullock JM, Donoso PJ, Landhäusser SM, Madsen P, Peng S, Rey-Benayas JM, Weber JC. 2015. Restoring forests: What constitutes success in the twenty-first century?. New For 46: 601-614.

Khaing N, Mitloehner, R. 2014. Structure and composition of dry deciduous forests in Central Myanmar. Proceedings of the in Annual Conference of Forest Research Institute. Nay Pyi Taw, Myanmar. November 2014. [Myanmar]

Li X, Liu W, Tang CQ. 2010. The role of the soil seed and seedling bank in the regeneration of diverse plant communities in the subtropical Ailao Mountains, Southwest China. Ecol Res 25 (6): 1171-1182.

Lu Y. Ranjitkar S, Harrison RD, Xu J, Ou X, Ma X, He J. 2017. Selection of native tree species for subtropical forest restoration in Southwest China. PloS One 12 (1): e0170418. DOI: 10.1371/journal.pone.0170418.

Meyers, K. 2014. Assessment of the Readiness of Natma Taung National Park and Indawgyi Wildlife Sanctuary for World Heritage Nomination. Tech. Rep. UNESCO, Bangkok.

Myat AM. 2016. Vegetation Analysis of Semi-evergreen Montane Forest in Natma Taung National Park (Mt. Victoria), Chin State, Myanmar. [Dissertation]. Georg-August-Universität Göttingen, Fakultät für Forstwissenschaften und Waldökologie University, Göttingen. [Germany]

Myint M, Myint AA, Thein KM, Mon MS, Aung HL, Htoo KK, Aung N, Oo YLMM, Wai P, Aung PP. 2017. Designing Cluster Plots for National Level and Sub-National Level Forest Inventory for UnREDD National Forest Monitoring System of Myanmar (Part-1). Institute for Environmental Sciences (ISE), University of Geneva.

Narayan CA, Anshumali J. 2015. Diversity indices and importance values of a tropical deciduous forest of Chhotanagpur plateau, India. J Biodiv Environ Sci 7: 358-367.

Rana SK, Rana HK, Shrestha KK, Sujakhu S, Ranjitkar S. 2018. Determining bioclimatic space of Himalayan alder for agroforestry systems in Nepal. Plant Divers 40 (1): 1-8.

Réjou-Méchain M, Pélissier R, Gourlet-Fleury S, Couteron P, Nasi R, Thompson JD. 2008. Regional variation in tropical forest tree species composition in the Central African Republic: An assessment based on inventories by forest companies. J Trop Ecol 663-74.

Senpaseuth P, Navanugraha C, Pattanakiat S. 2009. The estimation of carbon storage in dry evergreen and dry dipterocarp forests in Sang Khom District, Nong Khai Province, Thailand. Environ Nat Resour J 7 (2): $1-1$.

Sharma CM, Suyal S, Gairola S, Ghildiyal SK. 2009. Species richness and Diversity along an altitudinal gradient in moist temperate forest of Garhwal Himalaya. J Am Sci 5 (5): 119-28.

Sofia B, Karishma K. 2013. Symplocos laurina: an unexplored important medicinal plant of Shola forest system. Intl J Med Aromat Plants 3 (3): 366-74.

Suryanto P, Rinarno YDBM, Prianto SD, Hendro Y, Hosaka T, Numata S. 2017. Recovery of vegetation structure, soil nutrients and latesuccession species after shifting cultivation in Central Kalimantan, Indonesia. J Trop For Sci 1: 151-62.

Walker LR, del Moral R. 2009. Lessons from primary succession for restoration of severely damaged habitats. Appl Veg Sci 12 (1): 55-67.

Yirdaw E, Monge AM, Austin D, Toure I. 2019. Recovery of floristic diversity, composition and structure of regrowth forests on fallow lands: implications for conservation and restoration of degraded forest lands in Laos. New For 50 (6): 1007-1026. 
Zin IIS. 2017. Status and Management of Tanintharyi Nature Reserve,

Göttingen. [Germany] Tenasserim in Myanmar. [Dissertation]. Cuvillier Verlag University, 